\author{
Vyacheslav I. Molodina, Alexander S. Pilipenkob, *, Aida G Romaschenkob, \\ Anton A. Zhuravlev ${ }^{b}$, Rostislav O. Trapezov ${ }^{b}$, Tatiana A. Chikishevaa, \\ Dmitriy V. Pozdnyakova
}

\title{
Human migrations in the southern region of the West Siberian Plain during the Bronze Age: Archaeological, palaeogenetic and anthropological data
}

\author{
* Corresponding author: alexpil@mail.ru \\ a Institute of Archaeology and Ethnography, Siberian \\ Branch, Russian Academy of Sciences, Novosibirsk, \\ Russia \\ b Institute of Cytology and Genetics, Siberian Branch, \\ Russian Academy of Sciences, Novosibirsk, Russia
}

\section{Abstract}

In this paper we present archaeological and anthropological data on human migrations in the Western Siberian foreststeppe region during the Bronze Age $\left(4^{\text {th }}\right.$-beginning of $\mathrm{I}^{\text {st }}$ mil-

\begin{abstract}
lennium BC). These data, accumulated over forty years of intensive research in the region, are compared to new results showing the diversity of mitochondrial DNA (mtDNA) lineages in this region during that period ( 92 mtDNA samples from seven ancient human groups). Preliminary analyses have demonstrated the usefulness of ancient DNA in tracing and unravelling patterns of past human migrations.
\end{abstract}

Keywords

West Siberian forest steppe, Bronze Age cultural groups, human migrations, ancient mtDNA

\section{Introduction}

Western Siberia is a vast area of approximately 3 million square kilometers in North Asia. It ranges from the Ural Mountains in the east to the Yenisei River in the west, and from the Arctic Ocean in the north to the mountainous regions of Central Asia in the south. The southern part of the region comprises zones of steppe and forest steppe and has been inhabited by anatomically modern humans since the Stone Age (Upper Palaeolithic period).

Our work is devoted to the analysis of human migration processes that occurred during the Bronze Age $\left(4^{\text {th }}-\right.$ early $\mathrm{I}^{\text {st }}$ millennium BC) in the forest steppe zone between the $\mathrm{Ob}$ and Irtysh rivers (about $800 \mathrm{~km}$ from west to east). This area, known as Baraba forest steppe, stretches over $200 \mathrm{~km}$ from the taiga zone in the north to the steppes in the south.

Several factors make the ancient Baraba populations interesting objects of study. Firstly, intensive archaeological research has been conducted in the Baraba region during the last 30 years. As a result, a large set of data about all ethno-cultural groups that occupied this territory, from about I4 thousand years ago to the Late Middle Ages, including the Bronze Age, is currently available. Secondly, the ancient human groups of Baraba exhibit all general features of the ancient West Siberian population, yet with some specific features (Molodin, I985, 200I). Thirdly, we have a unique collection of palaeoanthropological remains for all Baraba populations from the Bronze Age. The high degree of preservation of these bones enables their analysis using methods from both physical anthropology and molecular genetics. It is also important that these remains were obtained from burial grounds located within a small territory (Fig. I). As a result, the populations occupying this territory were to some extent culturally homogenous during each of the historical periods considered.

Using this material we have attempted to assess changes in the composition of mtDNA lineages in the gene pools of ancient Baraba populations during the Bronze Age, comparing the genetic results with the archaeological and anthropological evidence pointing to the putative migratory events thought to have occurred during this period. 


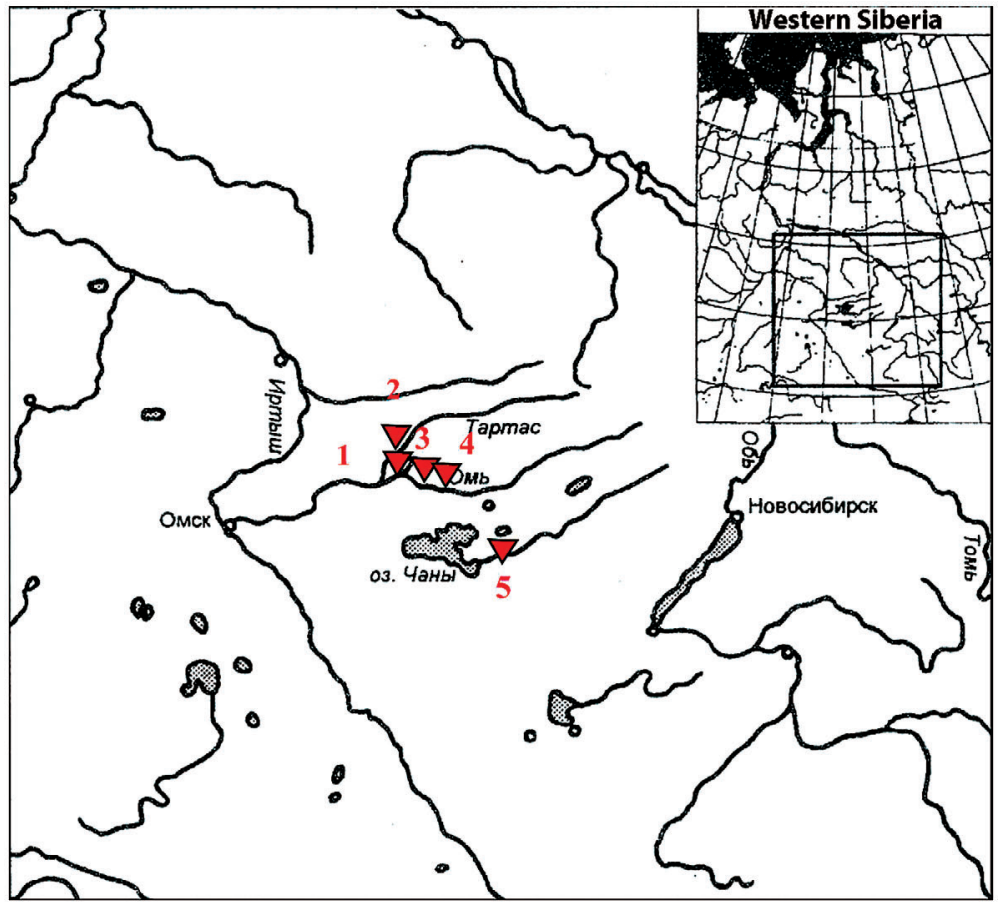

Fig. 1 | Location of the archaeological sites from which samples for the genetic studies were obtained. I Sopka-2; 2 Tartas-I; 3 Preobrazhenka-6; 4 Stariy Sad; 5 Chicha-I (including Kurgan Zdvinsk-I)

Table 1 | The Bronze Age West Siberian cultural groups studied

\begin{tabular}{|c|c|c|c|}
\hline Ancient human group & $\begin{array}{l}\text { Date } \\
\text { (millennium BC) }\end{array}$ & $\begin{array}{l}\text { Archaeological } \\
\text { sites }\end{array}$ & Periods \\
\hline Ust-Tartas Culture & $4^{\text {th }}-$ first half of $3^{\text {rd }}$ & $\begin{array}{l}\text { Sopka-2/3, } \\
\text { Sopka-2/3A }\end{array}$ & Early Metal Period \\
\hline Odinovo Culture & Beginning of $3^{\text {rd }}$ & $\begin{array}{l}\text { Sopka-2/4A } \\
\text { Preobrajenka-6 }\end{array}$ & Early Bronze Age \\
\hline Early Krotovo Culture & End of $3^{\text {rd }}-$ beginning of $2^{\text {nd }}$ & Sopka-2/4B & Middle Bronze Age \\
\hline Late Krotovo Culture & First quarter of $2^{\text {nd }}$ & Sopka-2/5, Tartas-I & Middle Bronze Age \\
\hline Andronovo (Fedorovo) Culture & First half of $2^{\text {nd }}$ & Tartas-I & Middle Bronze Age \\
\hline $\begin{array}{l}\text { Baraba Late Bronze } \\
\text { Age Culture }\end{array}$ & End of $2^{\text {nd }}$ & Stariy Sad & Late Bronze Age \\
\hline Late Irmen Culture & $9^{\text {th }}-8^{\text {th }}$ centuries $B C$ & Chicha-I & $\begin{array}{l}\text { Transition from Bronze } \\
\text { to Iron Age }\end{array}$ \\
\hline
\end{tabular}

\section{Materials and methods of the palaeogenetic study}

The ancient West Siberian groups studied are listed in Table I and Figure 2. DNA was extracted from the compact material of long bones (femur, tibia or humerus) and/or from the teeth. Whenever possible, samples were taken from different parts of the skeleton (eg, postcranial bone and tooth) from each individual. For a minority of individuals different parts of the same bone had to be used.

DNA was extracted according to the method described by Pilipenko and colleagues $(2008,2010)$. In brief, surfaces of bone and tooth samples were cleaned mechanically followed by treatment by bleach 
and UV. Bone powder was drilled from the internal area of the samples. DNA was extracted from the powder with a $5 \mathrm{M}$ guanidinium thiocyanate (GuSCN) buffer ( $\mathrm{pH}$ II.o) for 48 hours at $65^{\circ} \mathrm{C}$ followed by phenol/chlorophorm extraction. The DNA was precipitated from the aqueous phase with isopropanol in the presence $\mathrm{IM} \mathrm{NaCl}$. At least two extractions were conducted for each individual under study (in most cases, three).

Amplification of Hyper-Variable Region (HVR) I of mtDNA was performed using three different techniques: amplification using four overlapping fragments (Haak et al., 2005), amplification with primer pairs $\mathrm{HAI}$ and $\mathrm{HA}_{3}, \mathrm{HB}$ a and $\mathrm{HB}_{3}, \mathrm{HC}$ and $\mathrm{HC}_{3}$ that produced three overlapping fragments (Adcock et al., 200I) and nested PCR (two reaction rounds) that produced one long fragment (Pilipenko et al., 2008).

Cloning of PCR products and sequencing of clones have been performed for a half of the samples. For the remaining samples the cloning procedure is in progress. A set of PCR products was cloned with pGEM-T Easy Vector Sestem Kit (Promega, USA) and a minimum of 30 clones were sequenced for each individual.

Sequencing reactions were performed with an ABI Prism BigDye Terminator Cycle Sequencing Ready Reaction Kit (Applied Biosystems, USA), according to the manufacturer's instructions. The sequences of the products were analyzed on an ABI Prism 3100 Genetic Analyzer (Applied Biosystems, USA) at the DNA Sequencing Center (Novosibirsk, Russia, www.sequest.niboch.nsc.ru).

The sequencing results were analysed using Sequence Scanner vi.o (Applied Biosystems, USA) and DNAStar Lasergene v. 7.I.o (DNASTAR, USA) software. The phylogenetic tree was constructed using Network 4.5.I.o software (http://www.fluxus-engeneering.com).

Precautions against contamination: All stages of work with ancient material were carried out in specially equipped, isolated clean rooms with positive air pressure, using special cloth, facemasks, glasses and sterile gloves. All work surfaces were routinely cleaned with a $5 \%$ solution of bleach and irradiated by UV light. Blank controls were run in parallel with samples throughout the extraction and amplification procedures to identify possible contamination. MtDNA HVR I sequences were determined for all employees working with ancient DNA and (to the extent possible) for participants of excavations and anthropologists who might have had contact with remains.

\section{Results and discussions}

The degree of contamination and the authenticity of the aDNA results obtained

Despite the strict experimental conditions we were unable to eliminate the problem of contamination completely. In particular, contamination was ascertained in a small proportion of the extraction and PCR blank controls (less than I \% of control number). All extracts or PCR-products were discarded in such cases. Additionally, we identified singular divergent sequences among clones from several mtDNA samples studied. These sequences were regarded as the results of contamination as they were not reproducible in the second PCR or/and extraction. The other necessary conditions for the authenticity of obtained ancient DNA sequences were as follows: consistency of the results obtained in repeated PCR from one extract (for the same region or for several overlapping DNA fragments). Consistency between the results of multiple (at least two) DNA extractions (including extractions from different parts of the skeleton, such as the femur and teeth). The divergence of obtained aDNA sequences from those of staff members (geneticists, archaeologists, anthropologists) who may have had contact with the samples be- 

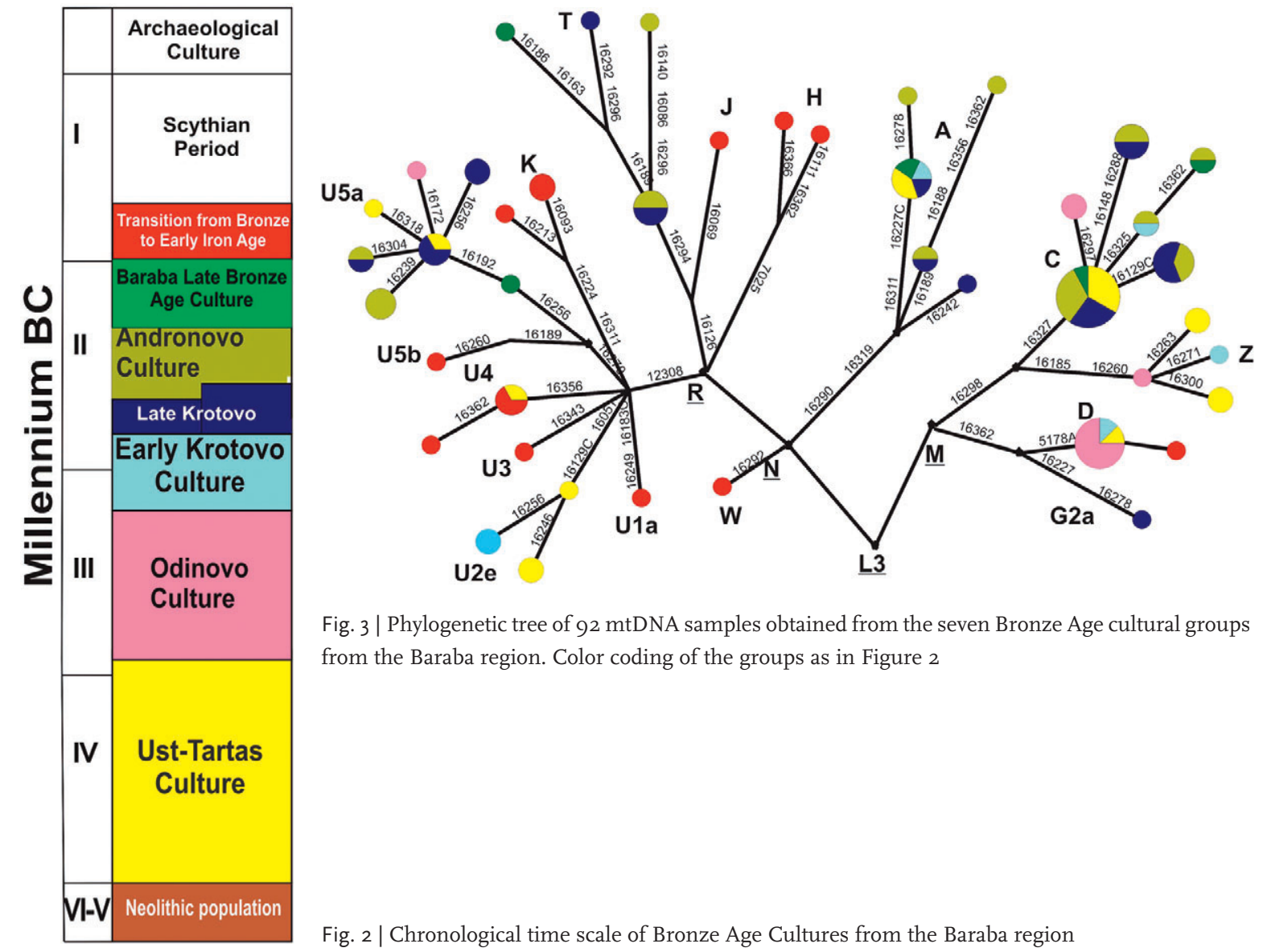

Fig. 3 | Phylogenetic tree of 92 mtDNA samples obtained from the seven Bronze Age cultural groups from the Baraba region. Color coding of the groups as in Figure 2

Fig. 2 | Chronological time scale of Bronze Age Cultures from the Baraba region

fore or during the genetic study. Presence among the clones of a specific pattern of biochemical degradation (cytosine deamination). In our opinion, these criteria meet the main modern requirements for verification of aDNA data.

In total, we successfully analyzed 92 mtDNA samples from seven ancient human groups from Baraba and adjacent areas (Fig. 3; Table 2-3 see appendix).

The genesis of West Siberian forest-steppe populations during the Neolithic and Early Metal periods

In order to estimate the impact of the migration waves on ethnogeny it is necessary to characterize the archaeological, anthropological and genetic contexts preceding the migratory events. For this purpose, it is also necessary to investigate the early populations of the region.

In contrast to the occupation of the southern region of West Siberia, modern humans arrived in the Ob-Irtysh interfluve relatively late, at the end of the Pleistocene, about I3-I4 thousand years ago (Okladnikov, Molodin, I983; Petrin, I986). The absence of burials dating back to this period in the region does not allow us to conduct a biological investigation of this earliest population. The most ancient anthropological material available is from the Neolithic period $\left(4^{\text {th }}-5^{\text {th }}\right.$ millennium BC). More than two dozen 
Fig. 4 | Typical collective burial of Ust-Tartas Culture representatives (Burial N 655, Sopka-2/3 burial ground)

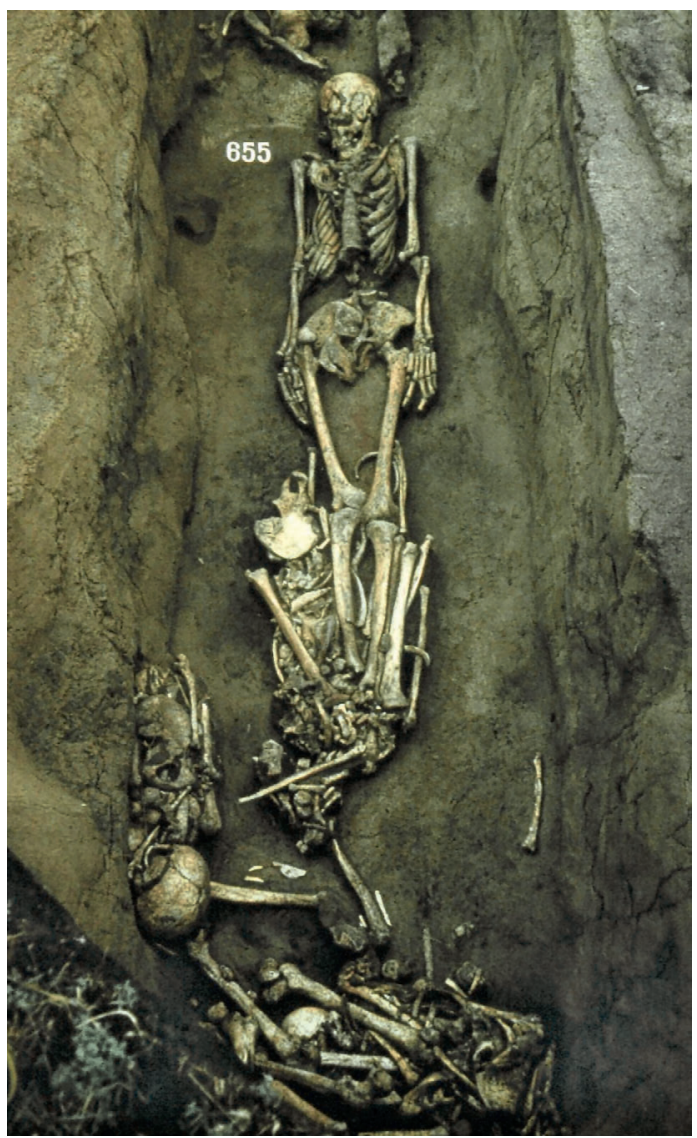

Neolithic burials have been excavated to date. The material from these excavations has allowed the characterization of specific aspects of the material culture and anthropological type of the Neolithic group (Polos'mak et al., I989; Molodin, 200I). The anthropological analysis of the material allowed us to detect a specific craniological type in the Baraba population, which was assigned to one of the anthropological formations discovered by V.V. Bunak in ${ }_{195} 6$ through the analysis of Neolithic materials from the northern forest zone of the East European Plain. Bunak called it the "northern Eurasian anthropological formation" (Bunak, I956).

This anthropological type developed in a zone that is intermediate to the geographic areas occupied by the classic Caucasoids and the Mongoloids. The exists substantial anthropological evidence showing a wide geographic distribution of this anthropological formation: from the Trans-Urals forest and the Barabian province of Western Siberia in the east to Karelia and the Baltic in the west (Chikisheva, 20IO).

It is therefore possible to determine the cultural and anthropological background that existed in the Baraba region in the beginning of the Bronze Age. The availability of a small number of materials suitable for DNA analysis will also allow us to determine the composition of mtDNA lineages of the Baraba population from the Neolithic (the first results have already been obtained, but are not discussed in this paper).

The earliest group from the Bronze Age in the Baraba region is represented by the Ust-Tartas population (Molodin, 200I). Several Ust-Tartas burial grounds with more than I50 graves have been excavated to date (Fig. 4), some of which revealed the presence of bronze adornments. The results of archaeo- 
logical and radiocarbon dating allow us to date this culture to between the $4^{\text {th }}$ millennium $\mathrm{BC}$ and the first half of the $3^{\text {rd }}$ millennium BC.

Another cultural group in the Baraba region existed contemporaneously with the Ust-Tartas culture, the "Comb-pit Ware culture". Unlike the Ust-Tartas, the materials from the Comb-pit Ware culture are associated predominantly with settlements. In addition, several burials have been investigated, making it possible to reconstruct the burial practices of this culture (Molodin, I985, 200I).

Representatives of the Ust-Tartas culture belonged to a single craniological type preceding the Neolithic populations of the region (Chikisheva, 20I0). Craniometric analyses of materials from burials with comb-pit ware also show the characteristic features of the northern Eurasian anthropological formation, but demonstrate greater affinity with the northern periphery of the West Siberian Neolithic cultures (Chikisheva, 20I0), suggesting a predominantly autochthonous development of the Baraba populations from the Early Metal period.

We have analyzed I8 mtDNA samples from the Ust-Tartas population to date (Fig. 3). The results obtained thus far allow us to draw several preliminary conclusions about the genetic background in the region in the beginning of the Bronze Age. By the Early Metal Period the mtDNA pool structure was already mixed and consisted of both Western and Eastern Eurasian haplogroups in nearly equal proportions. The eastern Eurasian mtDNA cluster was represented by Haplogroups A, C, Z, D, which are most typical of modern and perhaps ancient populations located in the east of the region studied. Haplogroups $\mathrm{C}$ and $\mathrm{D}$ were predominantly represented by widely distributed root haplotypes. A lineage of Haplogroup A that was detected in two Ust-Tartas samples represents a subcluster that is apparently characteristic of West Siberia and the Volga-Ural Region. The observed presence of Haplogroup Z lineages with a high frequency in the Ust-Tartas group was unexpected, since these lineages are nearly absent in the gene pool of modern indigenous West Siberian populations.

It is worth noting that the Western Eurasian mtDNA haplogroups in the Ust-Tartas series were represented only by Haplogroup U lineages, and specifically by the three subgroups - U2e, U4, U5ar. These results are in agreement with previous data indicating that Haplogroup U lineages (particularly Subgroups $\mathrm{U}_{5}$ and $\mathrm{U}_{4}$ ) predominated in Eastern, Central and Northern European hunter-gatherer groups from I4000 to 4000 years ago (Bramanti et al., 2009; Malmstrom et al., 2009), and possibly in earlier periods (Krause et al., 20I0). The geographic area within which this genetic feature is observed appears to be broad (Fig. 5). Apparently, Baraba was near the eastern periphery of this area.

\section{The Early and the beginning of Middle Bronze Age populations: an autochthonous evolution}

The local evolution of the cultural groups described above led to the emergence of a new group in the Baraba region in the beginning of the $3^{\text {rd }}$ millennium BC. This group, referred to as Odinovo culture, differed in terms of their grave goods and funerary practices (Fig. 6) (Molodin, 2008).

The study of Odinovo culture settlements and several burial grounds with characteristic funerary practices showed that its carriers had well-developed bronze casting and weapons of the Seima-Turbino type (Molodin, 2008). The material culture of this group combined features of the preceding Comb-pit ware and Ust-Tartas archaeological cultures. It is possible that both these substrates were involved in the formation of the Odinovo culture. Anthropological evidence confirms the autochthonous development of the culture. An anthropological affinity of the group to the Ust-Tartas and the Neolithic craniological series from the Baraba forest steppe has been established (Chikisheva, 20I0). 


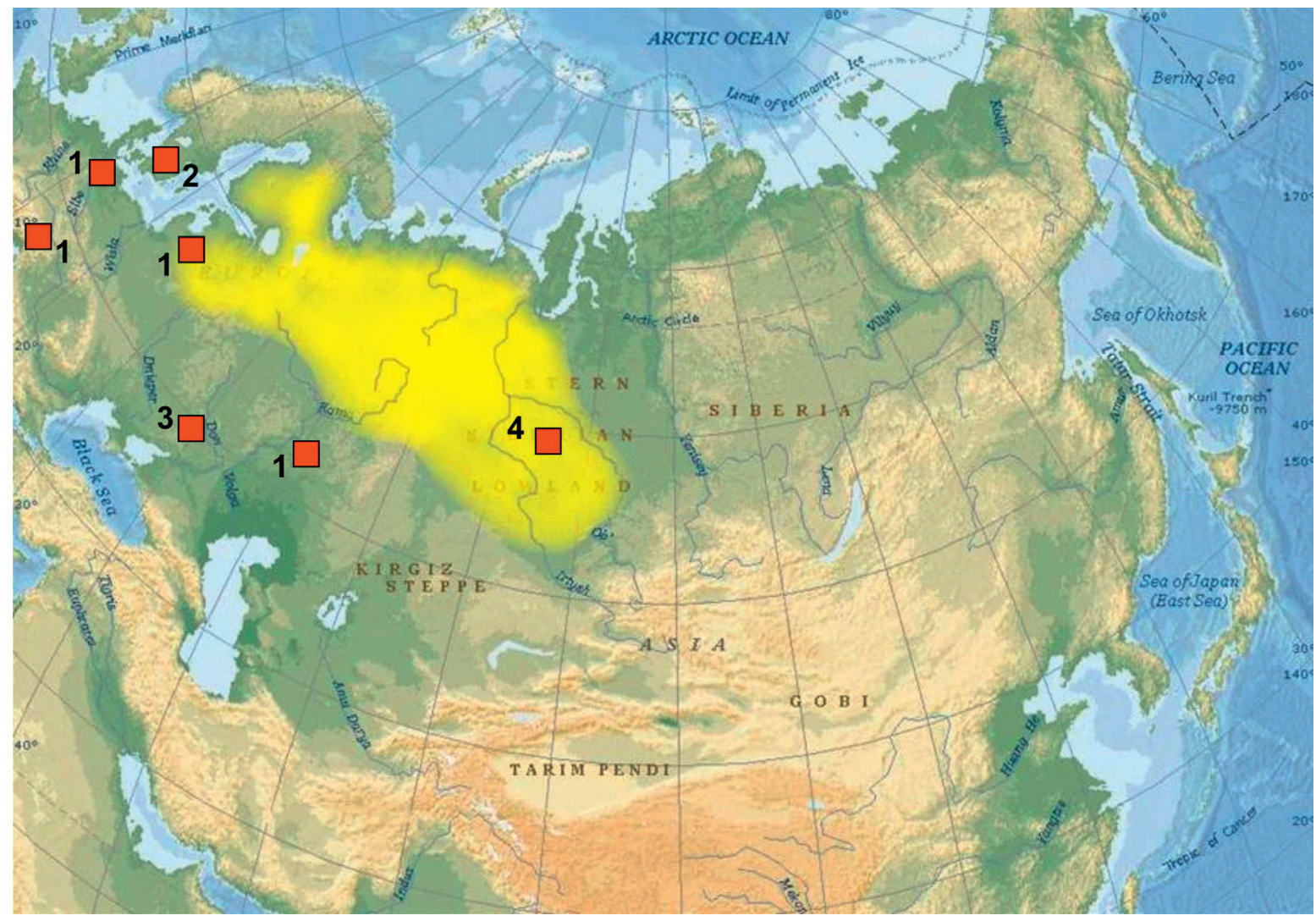

Fig. 5 | Location of ancient human groups with a high frequency of mtDNA haplogroups $\mathrm{U}_{5}$, U4 and U2e lineages. The area of Northern Eurasian anthropological formation is marked by yellow region on the map (References: I Bramanti et al., 2009; 2 Malmstrom et al., 2009; 3 Krause et al., 2010; 4 this study)

At the end of the $3^{\text {rd }}$ and beginning of the $2^{\text {nd }}$ millennium BC, a striking and original culture existed in the West Siberian forest steppe zone. The culture, known as Krotovo, obviously developed autochthonally (Molodin, I985). Undoubtedly, one of its ancestral components was the preceding Odinovo group. However, undeniable innovations are observed in the Krotovo funerary practices and inventories. These new features were probably associated with episodic migrations of representatives of the Petrovo culture from the modern North Kazakhstan territory (Zdanovich, I988) to the Baraba forest steppe. Moreover, present among the Krotovo materials were specific forms of daggers, stalked spearheads and beads of chalcedony, jaspilite and enstatite (the nearest deposits of these minerals are located in Central Asia and Kazakhstan) (Fig. 7a,b,c), suggesting the influence of Central Asian cultures in the Baraba region during

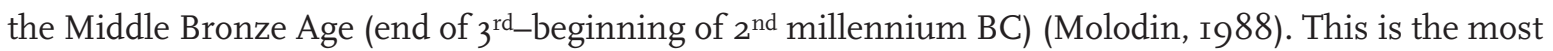
ancient external influence on the material culture of the Baraba population from the Bronze Age that might have been accompanied by a migration wave.

The craniological analysis of early Krotovo populations, however, showed the presence of an autochthonous morphological complex that was typical of earlier groups in the region, except for a higher cranium in Krotovo males (Chikisheva, 2010).

The genetic analysis of the Odinovo and Krotovo groups (Io and 6 samples, respectively) (Fig. 3) did not reveal any differences between them and the previous Ust-Tartas group, such as the presence of new mtDNA haplogroups. The mtDNA pool structure was still mixed. The East Eurasian haplogroups were 


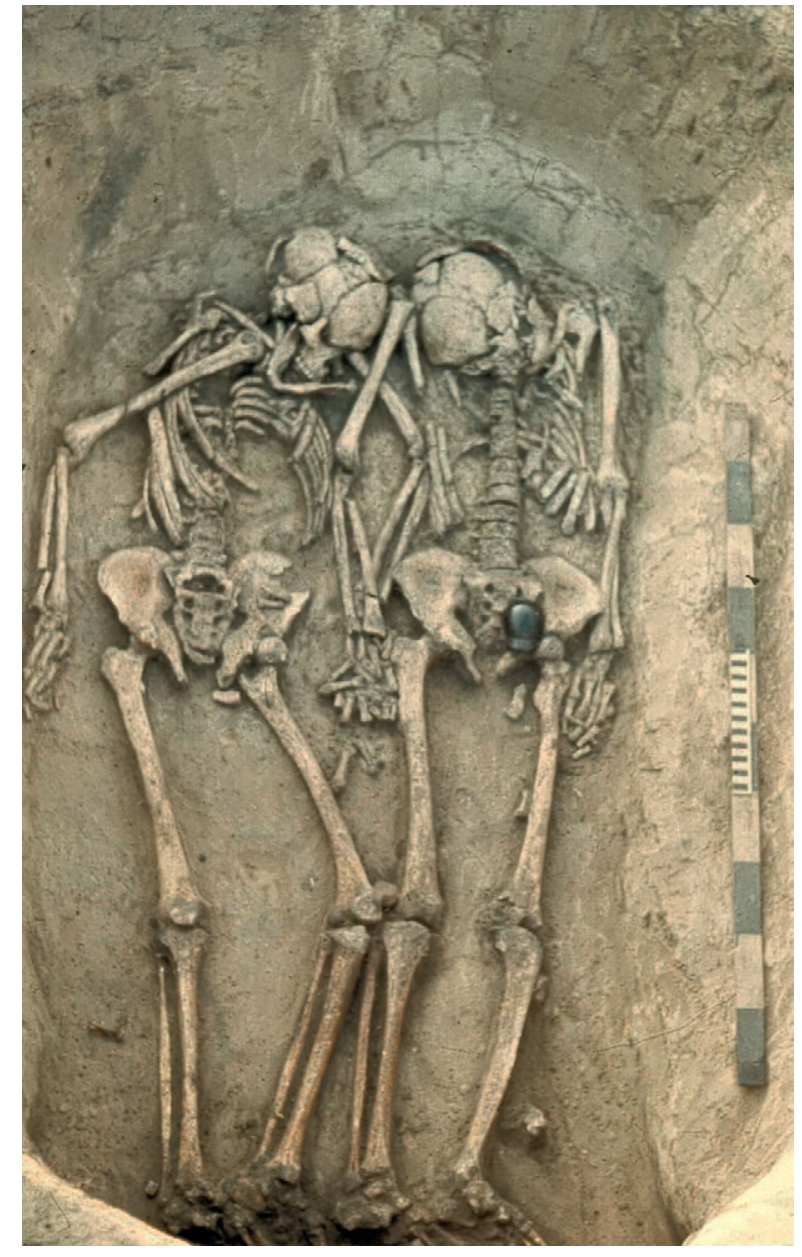

Fig. 6 | A burial of Odinovo culture representatives (Sopka-2/ 4A burial ground)

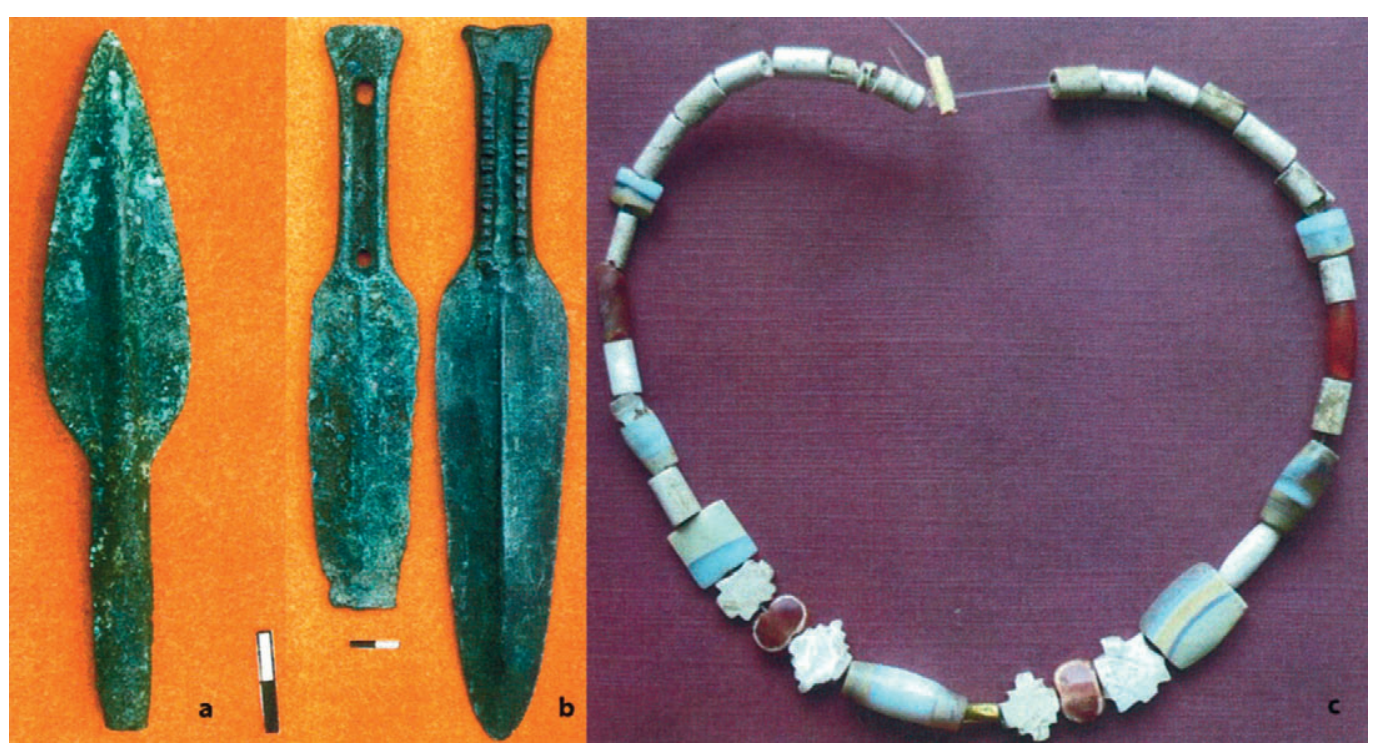

Fig. 7 | Specific spearhead (a), daggers (b) and beads (c) from the Early Krotovo Culture sites, indicating the influence of Central Asian cultures in the Baraba region during the Middle Bronze Age 
represented by the D, C, Z (in both the Odinovo and Krotovo groups) and A (in the Krotovo group) haplogroups. The East Eurasian lineages identified were phylogenetically close (lineages of haplogroups A, C, Z) or even identical (D haplogroup, $\mathrm{I}_{2223}-\mathrm{I}_{3} \mathrm{G}_{2}$ lineages) to the samples from the Ust-Tartas group. The West Eurasian part of the samples were represented by the U5ai (Odinovo group) and U2e (Krotovo group) haplogroup lineages.

Although only a small series of samples have been investigated thus far, the data obtained reveal continuity between the Odinovo and Krotovo populations and the earlier Ust-Tartas group. These findings are consistent with the autochthonous development of the Baraba populations during the Early and the beginning of the Middle Bronze Age, as well as with the anthropological evidence.

Our data did not allow us to detect any Central Asian genetic influence on the Krotovo population, although this conclusion is still preliminary due to the small sample sizes involved.

\section{The Middle and Late Bronze Age: significance of the Andronovo (Fedorovo) population migration wave}

The Krotovo culture continued to develop indigenously for several centuries. At the beginning of the $2^{\text {nd }}$ millennium BC, the migration of the Andronovo culture population to the south of the West Siberian Plain started, probably originating in the territory of present-day Central Kazakhstan. Apparently, this migration wave, which spread from its epicenter to the west, north and east (Kuz'mina, 1994), was a highly significant phenomenon in Asia.

The newly arrived Caucasian Andronovo population had a great influence on the development of the indigenous cultures of the West Siberian steppe and forest steppe regions (including the Baraba forest steppe). According to the archaeological evidence, the newly arrived groups coexisted with the aborigines for some time, which can be explained by the differing nature of their economic activities (nomadic and seminomadic pastoralism in the Andronovo group and sedentary or semisedentary pastoralism in the aboriginal Late Krotovo group). During this time the migrants had a strong impact on the material culture of the indigenous group. As a result, the bronze weapons and adornments of the aboriginal cultural group changed from Seima-Turbino to Srubno-Andronovo forms (Fig. 8a; 9a). The contact between these two groups is also reflected in their funerary practices and inventories, which combined novel and traditional features of the Baraba region. Archaeological evidence indicates that the Andronovo impact on the Late Krotovo population was in fact manifold.

The adaptation of the migrant Andronovo group in the West Siberian forest steppe was a long process that resulted in the absolute dominance of this population in the region. The Krotovo populations were partially displaced to the north and partly assimilated. The material and spiritual culture of the Andronovo group in West Siberia gradually returned to its classical tradition (Fig. 8b; 9b), although with some new unique features.

At the late stage of the development of the Krotovo culture, the craniological complex had changed markedly in comparison to the anthropological type common in all preceding Neolithic and Bronze Age populations in the Baraba region. The changes observed in males from the Late Krotovo group could be attributed to the influence of Andronovo representatives. Some Mongoloid features, which were not related to the previous autochthonous substrate, appeared in females from the Late Krotovo group. The Europoid component observed in these females does not fall within the generally accepted criteria for the Andronovo anthropological type. 


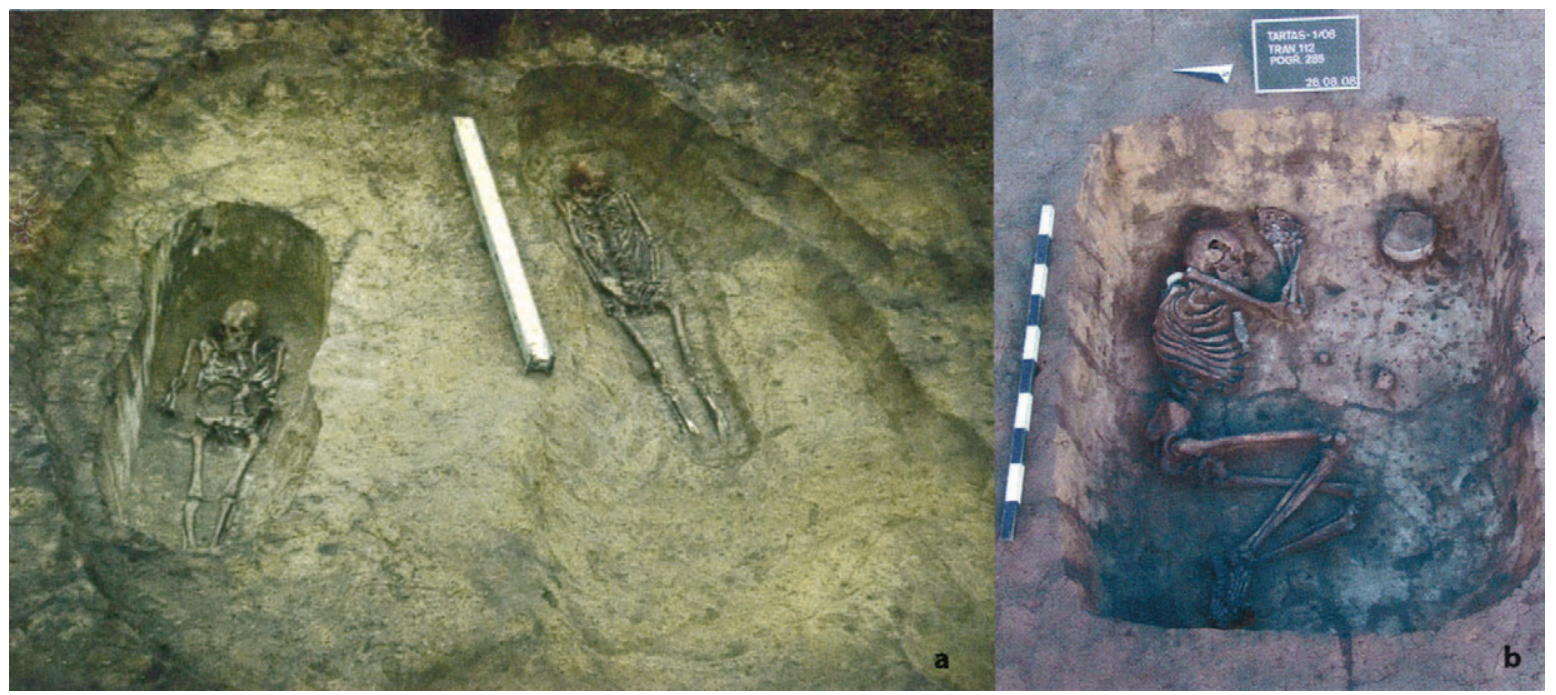

Fig. 8a | Typical burials of the Late Krotovo Culture; b. typical burial of the Andronovo (Fedorovo) Culture
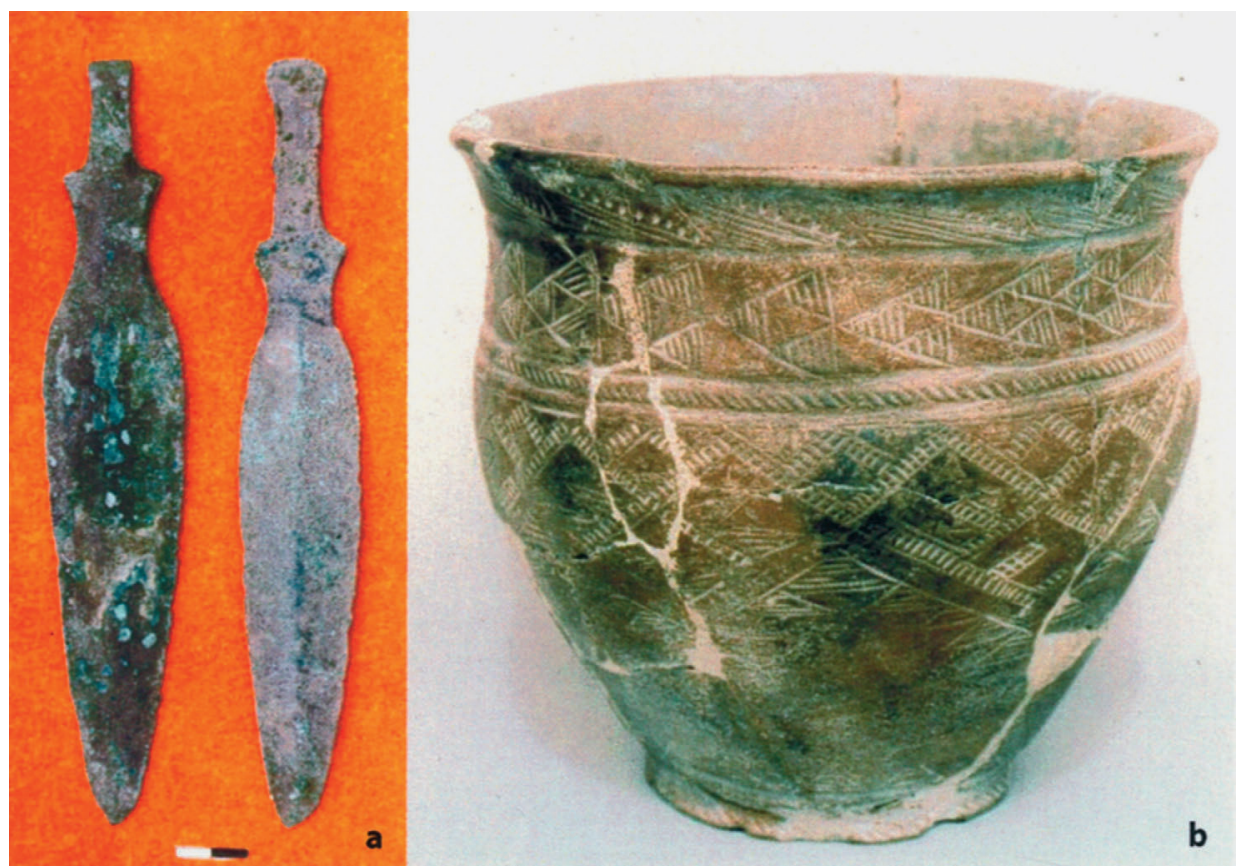

Fig. 9a | Daggers of Srubno-Andronovo form; b. Ceramic pot with specific ornamentation of the Andronovo (Fedorovo) Culture 
Some anthropological data suggest that the Krotovo population probably did not interact directly with the Andronovo populations, but rather with population groups displaced from the south and west by the Andronovo migration wave. In these groups, the Andronovo influence was already present (Chikisheva, 20I0).

The anthropological analysis of representative groups of the local Andronovo culture in southern West Siberia revealed a complex population composition. It suggests the existence of different genetic roots and different degrees of involvement of autochthonous Mongoloid component in their genesis.

The anthropological analysis of the West Siberian Andronovo population shows at least four craniological types. Three types are related to the Palaeocaucasian race and are represented by proto-European anthropological type variants. The fourth, Mongoloid, component is autochthonous. The most intensive interactions between the Andronovo migrants and the indigenous populations apparently occurred in the Baraba forest steppe and the right bank of the upper Ob River (Chikisheva and Pozdnyakov, 2003).

To investigate the putative impact of Andronovo migrants on the mtDNA pool structure of the indigenous populations in Baraba, mtDNA samples from the Late Krotovo $(n=20)$ and Andronovo $(n=20)$ groups in this region were analyzed (Fig. 3) and compared to recently published data ( $\mathrm{n}=\mathrm{IO})$ (Keyser et al., 2009) and our own unpublished data $(n=6)$ on mtDNA lineages from West Siberian Andronovo populations located outside the Baraba forest steppe.

The genetic influence of migrants can be detected by the appearance of a new mtDNA haplogroup that was absent in the populations preceding the migration wave. This new mtDNA haplogroup, a West Eurasian T haplogroup, was detected in the Late Krotovo population. The T haplogroup appears simultaneously (with a $15 \%$ frequency) in the Krotovo and Andronovo groups, but was completely absent in all preceding Baraba populations. We therefore consider the appearance of the Haplogroup T-lineage as the most likely genetic marker of the Andronovo migration wave to the region.

This assumption is confirmed by mtDNA studies of Andronovo groups from other West Siberian areas. Haplogroup T lineages were found, with a frequency of $25 \%$, in the samples $(n=16)$ taken from two Andronovo groups from the Krasnoyarsk and upper Ob River areas.

We also detected another remarkable feature in the mtDNA pool of the Andronovo group from Baraba. Most mtDNA samples belonged to haplogroups, such as the East Eurasian A and C haplogroups, that are typical of preceding Baraba indigenous populations. Still, these haplogroups were not found in the other West Siberian Andronovo groups. Apparently, the Andronovo group from Baraba assimilated the aboriginal Krotovo population, from which it obtained these East-Eurasian mtDNA haplogroups. Obviously, there was reciprocal genetic contact between the migrant and indigenous groups in the region.

The above mentioned ethno-cultural processes had a strong influence on the genesis of the cultural groups from the Late Bronze Age in this area. The Andronovo group in the south of West Siberia was replaced by the Irmen culture, which was originally from the West Siberian steppe and forest steppe zones around the $\mathrm{I} 4^{\text {th }}$ century BC, and occupied the region extending from the Achinsk and Mariinsk forest steppe in the east to the Irtysh River in the west (Molodin, I985; Bobrov et al., I993; Matveev, I993). The culture existed in the region for more than five hundred years and was characterized by a powerful economy, which included animal husbandry and agriculture.

A considerable number of Irmen culture settlements and burial grounds have been investigated. As a result, the characteristic features of the Irmen ceramics, inventory and funerary practices have been identified. However, the processes underlying the development of this group are not yet completely 
understood. Obviously, one major component in the genesis of the group is represented by the preceding Andronovo population, which had already assimilated features from West Siberian aborigines.

Analysis of the anthropological material from the Irmen culture in the Baraba region showed that their average craniological features are consistent with Caucasoid values, or indicate the presence of a small Mongoloid admixture. Anthropologically, the local Irmen group from Baraba was relatively homogenous. The results of the cross-group statistical analysis confirm the participation of the Andronovo population in the development of the anthropological type of all local Irmen groups (Chikisheva, 20IO).

The study of mtDNA samples from the Irmen population is at an early stage and will not be discussed in this paper.

The Irmen population engaged in intense contact with neighbouring groups in different parts of its vast territory. These interactions are reflected in the peculiarities of its material and spiritual culture and in the structure of the Irmen population as based on the physical anthropology data available. In the east, the Irmen population interacted with the neighbouring Karasuk culture group (Chlenova, I972). In the west, including the Baraba forest steppe region, interactions with neighbours were of a different nature. Several migration waves to Baraba occurred in this period. The first was associated with the migration of representatives of the Suzgun culture from the north-west. Accordingly, a syncretic culture, known as the Baraba variant of Suzgun culture, emerged in the northern part of the Baraba forest steppe (Molodin, Chemyakina, I984). Two other migratory waves simultaneously occurred in the southern part of the West Siberian forest steppe. The first was associated with the Roller Ware Culture, which occupied the vast Eurasian steppes during the Late Bronze Age (Chernykh, I983). This population also spread from the West Siberian steppe zone up to Kulunda steppe in the east. Apparently, a small proportion of this group migrated to the southern forest steppe, as evidenced by the presence of roller ware in the Irmen settlements (Molodin et al., 2000).

The largest migration wave to the steppe and forest steppe zones of Western Siberia was that of the Begazy-Dandybay populations during the Final Bronze Age, who came from the territory currently corresponding to modern Central Kazakhstan. The adaptation of these populations in the West Siberian steppe zone resulted in the development of syncretic groups, which then spread farther north and east. One such group was the Pahomov culture (Korochkova, 2009). This group migrated to the Baraba forest steppe and interacted intensively with the Irmen and Suzgun populations. A consequence of this process is the emergence of archaeological sites, such as the Stariy Sad burial ground in the Baraba region, where specific burial practices and anthropological types are found (Molodin and Neskorov, I992). This cultural group is referred to as Baraba Late Bronze Age culture. The anthropological analysis revealed differences between males and females in the population that cannot be explained by sexual dimorphism. This suggests that the series originated from anthropologically similar but not identical sources. The main craniological type detected in the population is similar to the Southern Eurasian Anthropological Formation. The female series shows similarities with the Andronovo populations from Northern Kazakhstan, which suggests that the latter populations were involved in the development of the Baraba Late Bronze Age culture. Alternatively, the specific pattern of marriage may have caused the migration of females from the Begazy-Dandybay population, which possibly brought the southern ceramic tradition to the Baraba region (Chikisheva, 20I0).

A small but informative series of mtDNA samples from the Baraba Late Bronze Age culture population ( $\mathrm{n}=5$ ) was analyzed (Fig. 3), revealing the presence of MtDNA lineages (East Eurasian A and C lineages) that mark the genetic continuity with aboriginal Baraba groups. At the same time, the series includes the Haplogroup-T lineage, which we believe marks the Andronovo migration wave to West 
Siberia. Our data is therefore consistent with the putative origin of the West Siberian Late Bronze Culture population as the result of interaction between the Baraba indigenous genetic substrate and the newly arrived group. However, the migration of Begazy-Dandybay culture representatives to the Baraba region is still questionable.

\section{The transition from the Late Bronze Age to the Early Iron Age: a southern influence}

Thus, a complex ethno-cultural structure developed in the end of the Bronze Age in the West Siberian forest steppe region, becoming even more complex during the transition from the Bronze to the Early Iron Age $\left(9^{\text {th }}-8^{\text {th }}\right.$ century BC). The abrupt cooling of the climate of Western Siberia (at its strongest in the Holocene [Levina, Orlova, I993]) led to the deterioration of ecological conditions in the taiga zone. In consequence, intense migration of taiga populations to the forest steppe zone in the south occurred in the territory that extends from the Urals in the west to the Yenisei River in the east. As a result, an ensemble of syncretic archaeological cultures developed in the West Siberian forest steppe region, including the Gamajun, Krasnoozersk and Zavyalovo cultures. This powerful migration wave triggered intense movement of various ethnic and cultural groups in the forest, forest steppe and even steppe zones towards the meridional and latitudinal directions. The study of the Baraba forest steppe area suggests that such processes occurred. On the one hand, the autochthonous Irmen culture evolved into the Late Irmen culture, an evolutionary process that was detected in the materials obtained from a large number of archaeological sites. On the other hand, the discovery and excavation of the Chicha-I settlement in the south of the Baraba forest steppe demonstrated both the occasional appearance of migrants from the north (representatives of the Suzgun and even northern taiga Atlym cultures) and permanent migration flows of representatives from the Krasnoozersk culture from the north-west and from the Berlik culture from the Kazakhstan steppes in the south-west (Fig. Io) (Molodin et al., 2009). It is important to note that the members of the above mentioned cultural groups and the aboriginal Late Irmen group lived in different parts of the same settlement (Molodin and Parzinger, 2009). Obviously, this led to intense interactions between the ethno-cultural groups, resulting both in the combination of cultural traits and traditions, as well as in the genetic admixture of populations as a result of intergroup marriages.

The analysis of mtDNA samples from the Chicha-I population revealed some interesting patterns. Crucial changes in the composition of mtDNA haplogroups in the gene pool were observed as compared to the earlier Baraba groups studied (Fig. 3). Dominance of Western Eurasian haplogroups and the near absence of East Eurasian were observed. Additionally, several new West Eurasian haplogroups appeared in the region, including Haplogroups Uia, $\mathrm{U}_{3}, \mathrm{U}_{5} \mathrm{~b}, \mathrm{~K}, \mathrm{H}, \mathrm{J}$ and $\mathrm{W}$.

The phylogeographic analysis suggests that the distribution and diversification centres of several of these mtDNA haplogroups and specific lineages are located on the west and south west of the Baraba forest steppe region, on the territory corresponding to modern-day Kazakhstan and Western Central Asia (Fig. Io). Apparently, the migration wave from the south strongly influenced the gene pool of the Baraba population in the transitional period from the Bronze to the Early Iron Age. The impact of the northern human groups was probably less evident in the south of the Baraba forest steppe, at least at the mtDNA level.

The frequencies of the new haplogroups mentioned above in the mtDNA pools of modern West Siberian populations show a different pattern however. The haplogroup lineages Ura and $\mathrm{U}_{3}$ are found only sporadically in the modern populations. Conversely, Haplogroup $\mathrm{H}$ is one of the most frequent West 


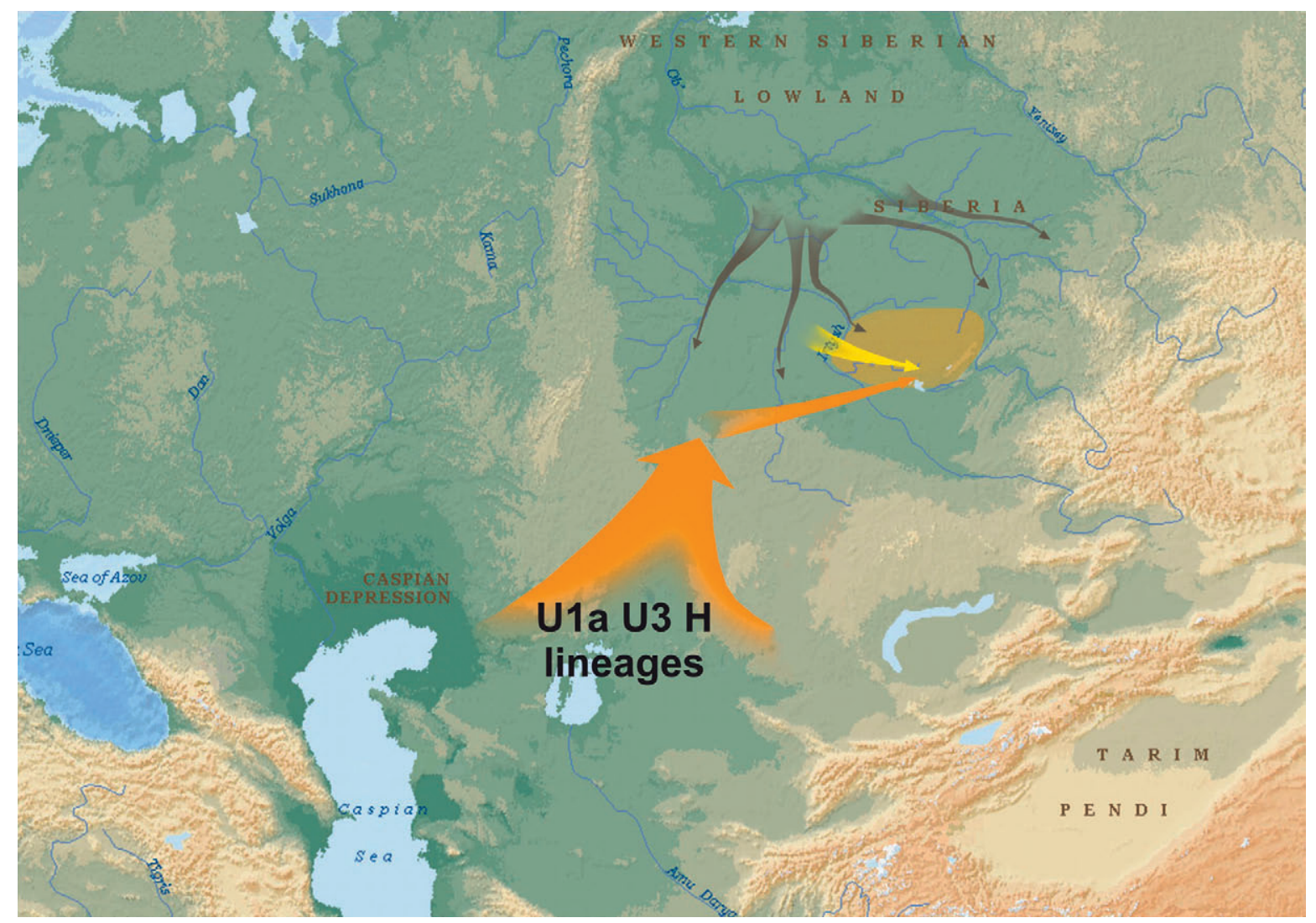

Fig. 10| Directions of migration waves in West Siberian forest steppe region during the transition from Bronze to Early Iron Age

Eurasian haplogroups in the modern indigenous populations of the region. Unexpectedly, the H-haplogroup lineages appear in the region only during the transition from the Bronze to the Early Iron Age.

Subsequently, in the Scythian-Sarmatian period, a large cultural group, called the Sargat culture, developed in the region. Its representatives were widespread across the region, from the Ob River to the Urals. Their development represented one of the most significant cultural events in North Asia.

\section{Conclusions}

According to the archaeological and anthropological evidence, the continuity between ethno-cultural groups from different periods and the inheritance of new cultural and genetic components as a result of several migration waves markedly affected the genesis of the populations in the West Siberian forest steppe zone during the Bronze Age.

Ancient mtDNA analyses have confirmed the key role played by autochthonous genetic components in composing the gene pool of the populations, especially during the Early and Middle Bronze Age. These components were represented by the Eastern Eurasian haplogroups A, C and Z, and the Western Eurasian haplogroup U5a.

On the other hand, the results also reveal some changes in the mtDNA pool structure throughout the Bronze Age. Some of these changes, which point to migration waves to the West Siberian forest 
steppe zone, are in agreement with the archaeological and anthropological evidence. The most relevant migration waves occurred during the Middle Bronze Age (represented by the migration of the Andronovo culture, probably marked by Haplogroup-T lineages) and the transition from the Bronze to the Iron Age (represented by the migration from the south, marked by the $\mathrm{U}_{\mathrm{ia}}, \mathrm{U}_{3}$ and $\mathrm{H}$ haplogroup lineages). These preliminary results indicate the usefulness of ancient DNA analysis as an additional tool for the reconstruction of migratory and ethnogenic processes in the Western Siberian region. To improve the efficacy of genetic methods it will be necessary to analyze other genetic markers in addition to mitochondrial DNA.

\section{References}

Adcock, G.J., Dennis, E.S., Easteal, S., Huttley, G.A., Jermiin, L.S., Peacock, W.J., Thorne, A., 200I. Mitochondrial DNA sequences in ancient Australians: Implications for modern human origins. Proceedings of the National Academy of Sciences of the USA 98 , 537-542.

Bobrov, V.V., Chikisheva, T.A., Mikhailov, Ju.N., I993. Mogil'nik epokhi pozdnei bronzy Zhuravlevo-4. Nauka, Novosibirsk.

Bramanti, B., Thomas, M.G., Haak, W., Unterlaender, M., Jores, P., Tambets, K., Antanaitis-Jacobs, I., Haidle, M.N., Jankauskas, R., Kind, C.-J., Lueth, F., Terberger, T., Hiller, J., Matsumura, S., Forster, P., Burger, J., 2009. Genetic discontinuity between local hunter-gatherers and central Europe's first farmers. Science 326 , I37-I4O.

Bunak, V.V., I956. Chelovecheskie rasy i puti ikh obrazovaniya. Sovetskaya etnografiya. 4, 86-105.

Chernykh, E.N., I983. Problema obshchnosti kul'tur valikovoj keramiki v stepyakh Evrazii, in: Bronzovyi vek stepnoi polosy Uralo-Irtyshskogo mezhdurech'ya. BashGU, Chelyabinsk, pp. 8I-99.

Chikisheva, T.A., 20I0. Dinamika antropologicheskoi differentsiatsii naseleniya yuga Zapadnoi Sibiri v epokhi neolita - rannego zheleznogo veka: Avtoreferat Doctoral Dissertation, Novosibirsk.

Chikisheva, T.A., Pozdnyakov, D.V., 2003. Naselenie zapadnosibirskogo areala andronovskoj kul'turnoj obshchnosti po antropologicheskim dannym. Arkheologiya, etnografiya i antropologiya Evrazii. I5 (3), I32-I48.

Chlenova, N.L., I972. Khronologiya pamjatnikov karasukskoi epokhi. Nauka, Moscow.

Haak, W., Forster, P., Bramanti, B., Matsumura, S., Brandt, G., Tanzem, M., Villems R., Renfrew, C., Gronenborn, D., Alt, K.W., Burger J. Ancient DNA from the first European farmers in 7500-year-old Neolithic sites. Nature 406, IоI6-IоI8.
Keyser, C., Bouakaze, C., Crubezy, E., Nikolaev, V.G., Montagnon, D., Reis, T., Ludes, B., 2009. Ancient DNA provides new insights into the history of south Siberian Kurgan people. Human Genetics I26, 395-4Io.

Korochkova, O.N., 2009. The Pakhomovskaya culture of the Late Bronze Age. Archaeology, Ethnology and Anthropology of Eurasia 37, 75-84.

Krause, J., Briggs, A.W., Kircher, M., Maricic, M., Zwyns, N., Derevianko, A., Paabo, S., 2oro. A complete mtDNA genome of an early modern human from Kostenki, Russia. Current Biology 20, I-6.

Kuz'mina, E.E., I994. Otkuda prishli Indoarii? Material'naya kul'tura plemen andronovskoi obshchnosti i proiskhozhdenie indoirantsev. Vostochnaya literatura, Moscow.

Levina, T.P., Orlova, L.A., I993. Klimaticheskie ritmy yuga Zapadnoj Sibiri. Geologiya i geofizika 3, 38-55.

Malmstrom, H., Gilbert, M.T.P., Thomas, M.G., Brandstrom, M., Stora, J., Molnar, P., Andersen, P.K., Bendixen, C., Holmlund, G., Gotherstrom, A., Willerslev, E, 2009. Ancient DNA reveals lack of continuity between Neolithic hunter-gatherers and contemporary Scandinavians. Current Biology I9, I758-I762.

Matveev, A.V., I985. Irmenskaya kul'tura v lesostepnoi Priob'e. NGU, Novosibirsk.

Molodin, V.I., I985. Baraba v epokhu bronzy. Nauka, Novosibirsk.

Molodin, V.I., I988. O yuzhnykh svyazyakh nositelei krotovskoi kul'tury, in: Istoriografiya i istochniki izucheniya istoricheskogo opyta osvoeniya Sibiri. Dosovetskij period. II FiF SO AN, Novosibirsk, pp. 36-37.

Molodin, V.I., 200I. Sopka-2 site on the Om river bank (the cultural-chronological analysis of the burial sites belonging to the Neolithic and Early Metal Periods). IAE SB RAS, Novosibirsk.

Molodin, V.I., 2008. Odinovskaya kul'tura v Vostochnom Zaural'e i Zapadnoi Sibiri. Problema vydeleniya, 
in: Rossiya mezhdu proshlym i budushim: istoricheskii opyt natsional'nogo razvitiya: Materialy Vserossiskoi Nauchnoi konferentsii Ekaterinburg, pp. 9-I3.

Molodin, V.I. Chemyakina M.A., I984. Poselenie Novochekina-3 - pamyatnik epokhi pozdnei bronzy na severe Barabinskoi lesostepi, in: Arkheologiya i etnografiya Yuzhnoi Sibiri. AGU, Barnaul, pp. 40-62.

Molodin, V.I., Myl'nikova, L.N., Durakov, I.A., Kobeleva, L.S., 2009. Kul'turnaya prinadlezhnost' gorodishcha Chicha-I po dannym statistiko-planigraficheskogo izucheniya keramicheskikh kompleksov na raznykh uchastkakh pamyatnika, in: Molodin. V.I., Parzinger H. (Eds.), Chicha- gorodishche perekhodnogo ot bronzy k zhelezu vremeni v Barabinskoi lesostepi. Novosibirsk, Berlin, pp. 44-50.

Molodin, V.I., Neskorov, A.V., I992. O svyazyah naseleniya Zapadnosibirskoi lesostepi i Kazakhstana v epokhu pozdnei bronzy. Margulanovskie chteniya. Tom I. Moscow, pp, 93-97.

Molodin, V.I., Novikov, A.V., Sofejkov, O.V., 2000. Arkheologicheskie pamyatniki Zdvinskogo rayona Novosibirskoi oblasti. Novosibirsk.

Molodin, V.I., Parzinger, H., 2009. Khronologiya pamyatnika Chicha-I, in: Molodin. V.I., Parzinger $\mathrm{H}$. (Eds.), Chicha-gorodishche perekhodnogo ot bronzy k zhelezu vremeni v Barabinskoi lesostepi. Novosibirsk, Berlin, pp. 5I-77.

Okladnikov, A.P., Molodin, V.I., I983. Palaeolit Baraby, in: Palaeolit Sibiri. Nauka, Novosibirsk, pp. IOI-Io6.

Petrin, V.T., I986. Palaeoliticheskie pamyatniki Zapadno-Sibirskoi ravniny. Nauka, Novosibirsk.

Pilipenko, A.S., Romaschenko, A.G., Molodin, V.I., Kulikov, I.V., Kobzev, V.F., Pozdnyakov, D.V., Novikova, O.I., 2008. Infant burials in dwellings at Chicha-I, in the Baraba forest-steppe: results of DNA analysis. Archaeology, Ethnology and Anthropology of Eurasia 34, 57-67.

Pilipenko, A.S., Molodin, V.I., Romaschenko, A.G., Parzinger, H., Kobzev, V.F., 20IO. Mitochondrial DNA studies of the Pazyryk people $\left(4^{\text {th }}\right.$ to $3^{\text {rd }}$ centuries BC) from northwestern Mongolia. Archaeological and Anthropological Sciences 2, 23I-236.

Polos'mak, N.V., Chikisheva, T.A., Balueva, T.S., I989. Neoliticheskie mogil'niki Severnoi Baraby. Nauka, Novosibirsk.

Zdanovich, G.B., I988. Bronzovyi vek Uralo-Kazakhstanskikh stepei (osnovy periodizatsii). Izdatel'stvo Uralskogo Gosudarstvennogo Universiteta, Sverdlovsk. 
Table 2 | List of samples from Baraba forest-steppe Bronze Age populations studied

\begin{tabular}{|c|c|c|c|c|c|}
\hline $\begin{array}{l}\text { Sample } \\
\text { number }\end{array}$ & $\begin{array}{l}\text { Sample } \\
\text { name }\end{array}$ & $\begin{array}{l}\text { Archaeological } \\
\text { site }\end{array}$ & $\begin{array}{l}\text { Burial number } \\
\text { (skeleton number)a }\end{array}$ & Archaeological culture & $\begin{array}{l}\text { MtDNA } \\
\text { haplogroup }\end{array}$ \\
\hline I & Ut2 & Sopka-2/3 & 600 & Ust-Tartas & U2e \\
\hline 2 & Ut3 & Sopka-2/3 & $655(C)$ & & D \\
\hline 3 & Ut4 & Sopka-2/3 & $655\left(\mathrm{D}_{2}\right)$ & & $\mathrm{C}$ \\
\hline 4 & Ut5 & Sopka-2/3 & $655\left(D_{4}\right)$ & & A \\
\hline 5 & Ut7 & Sopka-2/3A & $627(\mathrm{C})$ & & $\mathrm{C}$ \\
\hline 6 & Ut9 & Sopka-2/3A & $658(\mathrm{~A})$ & & U5aI \\
\hline 7 & UtI2 & Sopka-2/3A & 6II(K) & & $\mathrm{U}_{2} \mathrm{e}$ \\
\hline 8 & UtI4 & Sopka-2/3A & 619 & & U5aI \\
\hline 9 & Uti 6 & Sopka-2/3A & 6II(B) & & $\mathrm{C}$ \\
\hline IO & UtI7 & Sopka-2/3A & 6II $(\mathrm{C})$ & & $U_{2 e}$ \\
\hline II & Uti9 & Sopka-2/3A & 358 & & $\mathrm{U}_{4}$ \\
\hline I2 & Ut3I & Sopka-2/3A & $34 \mathrm{I}(3)$ & & $\mathrm{Z}$ \\
\hline I3 & Ut32 & Sopka-2/3A & 628 & & Z \\
\hline $\mathrm{I} 4$ & Ut33 & Sopka-2/3 & $656(F)$ & & Z \\
\hline I5 & Ut34 & Sopka-2/3 & $656(G)$ & & Z \\
\hline I6 & Ut37 & Sopka-2/3 & $655(\mathrm{~A})$ & & $\mathrm{C}$ \\
\hline I7 & Ut3 8 & Sopka-2/3 & $655(\mathrm{~B})$ & & A \\
\hline I8 & OdI & Preobrazhenka-6 & I8 & Odinovo & $\mathrm{C}$ \\
\hline I9 & $\mathrm{Od} 2$ & Preobrazhenka-6 & 2 & & Z \\
\hline 20 & $\mathrm{Od}_{3}$ & Preobrazhenka-6 & 36 & & $\mathrm{D}$ \\
\hline $2 \mathrm{I}$ & Odi2 & Sopka-2/4A & $184(2)$ & & D \\
\hline 22 & Odi3 & Sopka-2/4A & I94(I) & & D \\
\hline 23 & Od27 & Sopka-2/4A & $258(2)$ & & D \\
\hline 24 & Od29 & Sopka-2/4A & 523 & & $\mathrm{C}$ \\
\hline 25 & Od65 & Sopka-2/4A & $520(\mathrm{I})$ & & $\mathrm{D}$ \\
\hline 26 & Od66 & Sopka-2/4A & 594 & & U5ar \\
\hline 27 & Od67 & Sopka-2/4A & $588(\mathrm{I})$ & & D \\
\hline 28 & KrI & Sopka-2/4B & $407(\mathrm{I})$ & Early Krotovo & $\mathrm{C}$ \\
\hline 29 & $\mathrm{Kr} 5$ & Sopka-2/4B & I7I(I) & & Z \\
\hline 30 & Krio & Sopka-2/4B & I77(I) & & A \\
\hline $3 \mathrm{I}$ & Kr79 & Sopka-2/4B & 305 & & $\mathrm{U}_{2} \mathrm{e}$ \\
\hline 32 & Kr8o & Sopka-2/4B & 46 & & $\mathrm{U}_{2 \mathrm{e}}$ \\
\hline 33 & $\mathrm{Kr} 87$ & Sopka-2/4B & 65 & & $\mathrm{D}$ \\
\hline 34 & Pkri & Sopka-2/5 & IO8(I) & Late Krotovo & $T^{*}$ \\
\hline 35 & Pkr2 & Sopka-2/5 & 126 & & $\mathrm{~T}^{*}$ \\
\hline 36 & $\mathrm{Pkr}_{3}$ & Sopka-2/5 & I23 & & $U_{5} a^{*}$ \\
\hline 37 & Pkr4 & Sopka-2/5 & I4I & & $U_{5} a^{*}$ \\
\hline 38 & Pkr5 & Sopka-2/5 & II7 & & $T^{*}$ \\
\hline 39 & Pkr6 & Sopka-2/5 & $140(2)$ & & U5aI \\
\hline 40 & Pkr7 & Sopka-2/5 & $349(2)$ & & G2a \\
\hline $4 \mathrm{I}$ & Pkr8 & Sopka-2/5 & 334 & & A \\
\hline 42 & Pkr9 & Sopka-2/5 & 376 & & U5ar \\
\hline 43 & Pkrio & Sopka-2/5 & $625(\mathrm{I})$ & & $\mathrm{C}$ \\
\hline 44 & PkriI & Sopka-2/5 & I32 & & $\mathrm{C}$ \\
\hline 45 & TKI & Tartas-I & 85 & & C \\
\hline 46 & TK2 & Tartas-I & 77 & & $\mathrm{C}$ \\
\hline 47 & $\mathrm{TK}_{3}$ & Tartas-I & 76 & & A \\
\hline 48 & TK4 & Tartas-I & I5 & & C \\
\hline 49 & TK5 & Tartas-I & 73 & & U5aI \\
\hline 50 & TK6 & Tartas-I & 84 & & $\mathrm{C}$ \\
\hline $5^{\mathrm{I}}$ & TK7 & Tartas-I & $80(2)$ & & $\mathrm{C}$ \\
\hline 52 & TK8 & Tartas-I & 72 & & $\mathrm{C}$ \\
\hline
\end{tabular}


Table 2 | continued

\begin{tabular}{|c|c|c|c|c|c|}
\hline $\begin{array}{l}\text { Sample } \\
\text { number }\end{array}$ & $\begin{array}{l}\text { Sample } \\
\text { name }\end{array}$ & $\begin{array}{l}\text { Archaeological } \\
\text { site }\end{array}$ & $\begin{array}{l}\text { Burial number } \\
\text { (skeleton number)a }\end{array}$ & Archaeological culture & $\begin{array}{l}\text { MtDNA } \\
\text { haplogroup }\end{array}$ \\
\hline 53 & $\mathrm{TK} 2 \mathrm{I}$ & Tartas-I & 75 & & $\mathrm{~A}$ \\
\hline 54 & $\mathrm{TA}_{5}$ & Tartas-I & $227(\mathrm{I})$ & Andronovo (Fedorovo) & $\mathrm{T}^{*}$ \\
\hline 55 & $\mathrm{TA}_{4}$ & Tartas-I & $227(2)$ & & $\mathrm{T}^{*}$ \\
\hline 56 & TA7 & Tartas-I & $2 \mathrm{I} 8(\mathrm{I})$ & & A \\
\hline 57 & TA8 & Tartas-I & 225 & & $\mathrm{C}$ \\
\hline 58 & TA9 & Tartas-I & $2 \mathrm{I} 7(\mathrm{I})$ & & $\mathrm{C}$ \\
\hline 59 & TAio & Tartas-I & $2 \mathrm{I} 7(2)$ & & $\mathrm{U}_{5}$ aI \\
\hline 60 & TAiı & Tartas-I & $2 \mathrm{I} 3$ & & $\mathrm{U}_{5} \mathrm{aI}$ \\
\hline 6I & TAI3 & Tartas-I & $2 \mathrm{II}$ & & $\mathrm{C}$ \\
\hline 62 & TAi4 & Tartas-I & I80 & & $\mathrm{C}$ \\
\hline 63 & TAI5 & Tartas-I & I82(I) & & $\mathrm{T}^{*}$ \\
\hline 64 & TAi6 & Tartas-I & $182(2)$ & & $\mathrm{C}$ \\
\hline 65 & TAI7 & Tartas-I & 189 & & A \\
\hline 66 & TAi8 & Tartas-I & 223(I) & & $U_{5}$ aI \\
\hline 67 & $\mathrm{TA} 2 \mathrm{O}$ & Tartas-I & I88 & & $\mathrm{C}$ \\
\hline 68 & TA2I & Tartas-I & I96 & & $\mathrm{C}$ \\
\hline 69 & TA22 & Tartas-I & $208(\mathrm{I})$ & & $\mathrm{U}_{5} \mathrm{aI}$ \\
\hline 70 & TA23 & Tartas-I & 240 & & $\mathrm{C}$ \\
\hline 7I & TA25 & Tartas-I & I 24 & & A \\
\hline 72 & $\mathrm{TA}_{2} 6$ & Tartas-I & I37 & & $\mathrm{C}$ \\
\hline 73 & TA27 & Tartas-I & I76 & & $\mathrm{C}$ \\
\hline 74 & StsI & Stariy Sad & I & Baraba Late Bronze Age & $\mathrm{C}$ \\
\hline 75 & StsiI & Stariy Sad & 49 & & A \\
\hline 76 & Sts7 & Stariy Sad & 27 & & $\mathrm{C}$ \\
\hline 77 & Sts9 & Stariy Sad & 59 & & $\mathrm{U}_{5} \mathrm{a}$ \\
\hline 78 & Stsio & Stariy Sad & 62 & & $\mathrm{TI}$ \\
\hline 79 & $\mathrm{Ch}^{*} *$ & Chicha-I & Dio-BI & Baraba population of & $\mathrm{J}$ \\
\hline 80 & $\mathrm{Ch}_{2} *$ & Chicha-I & Dio-B2 & transition from the bronze & $\mathrm{H}$ \\
\hline $8 \mathrm{I}$ & $\mathrm{Ch}_{3} *$ & Chicha-I & $\mathrm{D} 20-\mathrm{BI}$ & to the Early Iron Age & $\mathrm{U}_{5} \mathrm{~b}$ \\
\hline 82 & $\mathrm{Ch}_{4} *$ & Chicha-I & $\mathrm{D}_{2} \mathrm{O}-\mathrm{B} 2$ & (Chicha-I Settlement & $\mathrm{U}_{4}$ \\
\hline 83 & $\mathrm{Ch}_{5} *$ & Chicha-I & D9-BI & population) & Uıа \\
\hline 84 & Ch6 & Chicha-I & D3a-BI & & $\mathrm{K}$ \\
\hline 85 & $\mathrm{Ch}_{7}^{*}$ & Chicha-I & D3a-B.2 & & K \\
\hline 86 & Ch8 & Chicha-I & D8-B.I & & $\mathrm{D}$ \\
\hline 87 & Chy & Chicha-I & IIIa & & $\mathrm{U}_{3}$ \\
\hline 88 & Chio & Chicha-I & I2 & & W \\
\hline 89 & CShII & Chicha-I & $6(2)$ & & $\mathrm{K}$ \\
\hline 90 & Chi2 & Zdvinsk-I & $\mathrm{I}(2)$ & & $\mathrm{U}_{4}$ \\
\hline 9I & $\mathrm{Ch} 33$ & Zdvinsk-I & 2 & & $\mathrm{U}_{4}$ \\
\hline 92 & Chi4 & Zdvinsk-I & 4 & & H6aI \\
\hline
\end{tabular}

a For the Chicha-I site burial designations indicate the following: for samples ChI-Ch8 (infants buried in dwellings of Chicha-I settlements) - D=dwelling number, $\mathrm{B}=$ burial number in that dwelling; Ch9 - individual was buried between dwellings in the section IIIa of the settlement territory; ChIO, II - individuals buried in the ground part of the Chicha-I necropolis; ChI2-I4 individuals buried in the kurgan part of the Chicha-I necropolis (previously designated "Zdvinsk-I")

* These samples were preliminarily published by Pilipenko and colleagues (2008), but were subsequently reanalyzed using more strict experimental conditions and verification criteria 
Table 3 | List of mtDNA HVR polymorphic sites

\begin{tabular}{|c|c|c|c|}
\hline $\begin{array}{l}\text { No of mtDNA } \\
\text { HVR I haplotype }\end{array}$ & $\begin{array}{l}\text { MtDNA } \\
\text { haplogroup }\end{array}$ & $\begin{array}{l}\text { mtDNA HVR I } \\
\text { polymorphic sites }\end{array}$ & Names of samples \\
\hline I & A & $223 \mathrm{~T}-227 \mathrm{C}-290 \mathrm{~T}-3 \mathrm{IIC}-319 \mathrm{~A}$ & Krio, TK, StsiI \\
\hline 2 & A & I48T-223T-227C-290'-3IIC-319A & $\mathrm{Ut}_{5}, \mathrm{Ut} 38$ \\
\hline 3 & A & 223T-227C-278T-290T-3IIC-319A & TAI7 \\
\hline 4 & A & I89C-223T-290T-319A & Pkr8, TA25 \\
\hline 5 & A & $223 \mathrm{~T}-242 \mathrm{~T}-290 \mathrm{~T}-319 \mathrm{~A}$ & TK2I \\
\hline 6 & A & I88T-189C-223T-29oT-319A-356C-362C & TA7 \\
\hline 7 & $\mathrm{C}$ & $223 \mathrm{~T}-298 \mathrm{C}-327 \mathrm{~T}$ & $\begin{array}{l}\text { Ut4, Ut7, Utı6, Ut37, Pkrio, TKI, } \\
\text { TK2, TA9, TAı3, TAı4, TAı6, Sts7 }\end{array}$ \\
\hline 8 & $\mathrm{C}$ & I29C-223T-298C-327T & TK6, TK7, TK8, TA26, TA27 \\
\hline 9 & $\mathrm{C}$ & $223 \mathrm{~T}-297 \mathrm{C}-298 \mathrm{C}-327 \mathrm{~T}$ & Od29, OdI \\
\hline IO & $\mathrm{C}$ & $223 \mathrm{~T}-298 \mathrm{C}-325 \mathrm{C}-327 \mathrm{~T}$ & KrI, TA23 \\
\hline II & $\mathrm{C}$ & $223 \mathrm{~T}-298 \mathrm{C}-325 \mathrm{C}-327 \mathrm{~T}-362 \mathrm{C}$ & TA8, Stsi \\
\hline $\mathrm{I} 2$ & $\mathrm{C}$ & I48T-223T-288C-298C-327T & Pkr II, TK4, TA2O, TA2I \\
\hline I3 & $\mathrm{D}$ & $223 \mathrm{~T}-362 \mathrm{C}$ & $\begin{array}{l}\mathrm{Ut}_{3}, \mathrm{Od}_{2}, \mathrm{Od}_{3}, \mathrm{Od}_{27}, \mathrm{Od}_{5}, \\
\mathrm{Od}_{7}, \mathrm{Od}_{3}, \mathrm{Kr}_{8} 7\end{array}$ \\
\hline I4 & $\mathrm{D}$ & $223 \mathrm{~T}-294 \mathrm{~T}-362 \mathrm{C}$ & Ch8 \\
\hline $\mathrm{I} 5$ & G2a & $223 \mathrm{~T}-227 \mathrm{G}-278 \mathrm{~T}-362 \mathrm{C}$ & Pkr7 \\
\hline I6 & $\mathrm{Z}$ & I85T-223T-26oT-298C-300G & Ut3I, Ut32 \\
\hline I7 & $\mathrm{Z}$ & I85T-223T-26oT-263C-298C & Ut33, Ut34 \\
\hline I8 & $\mathrm{Z}$ & I85T-223T-26oT-27IC-298C & $\mathrm{Kr} 5$ \\
\hline I9 & $\mathrm{Z}$ & $185 \mathrm{~T}-223 \mathrm{~T}-260 \mathrm{~T}-298 \mathrm{C}$ & $\mathrm{Od}_{2}$ \\
\hline 20 & Uıа & $183 \mathrm{C}-189 \mathrm{C}-249 \mathrm{C}$ & $\mathrm{Ch}_{5}$ \\
\hline $2 \mathrm{I}$ & $\mathrm{U}_{2 \mathrm{e}}$ & $\mathrm{I} 29 \mathrm{C}-\mathrm{I} 89 \mathrm{C}$ & Ut2 \\
\hline 22 & $\mathrm{U}_{2 \mathrm{e}}$ & I29C-189C-246G & Utı2, UtI7 \\
\hline 23 & $\mathrm{U}_{2 \mathrm{e}}$ & $129 \mathrm{C}-189 \mathrm{C}-256 \mathrm{~T}$ & Kr79, Kr8o \\
\hline 24 & $\mathrm{U}_{3}$ & $343 \mathrm{G}$ & Chy \\
\hline 25 & $\mathrm{U}_{4}$ & $356 \mathrm{C}$ & Utı9, Chı2, Chi3 \\
\hline 26 & $\mathrm{U}_{4}$ & $356 \mathrm{C}-362 \mathrm{C}$ & $\mathrm{Ch}_{4}$ \\
\hline 27 & U5ai & 192T-256T-270T & Ut9, Pkr6, TK5 \\
\hline 28 & U5aI & $192-256-270-318$ & UtI4 \\
\hline 29 & U5ai & $172-192-256-270$ & Od66 \\
\hline 30 & U5ai & $192-256-270-304$ & Pkr9, TAı8 \\
\hline $3 \mathrm{I}$ & U$_{5}$ aI & 192 T-239T-256T-270T & TA1o,TAir,TA22 \\
\hline 32 & $U_{5}$ a & $256 \mathrm{~T}-270 \mathrm{~T}$ & Sts9 \\
\hline 33 & $\mathrm{U}_{5} \mathrm{a}$ & I92T-270T & $\mathrm{Pkr}_{3}, \mathrm{Pkr}_{4}$ \\
\hline 34 & $\mathrm{U}_{5} \mathrm{~b}$ & I89C-26oT-270T & $\mathrm{Ch}_{3}$ \\
\hline 35 & $\mathrm{~K}$ & ${ }_{093} \mathrm{C}-224 \mathrm{C}-3 \mathrm{IIC}$ & Ch6, Ch7 \\
\hline 36 & $\mathrm{~K}$ & $2 \mathrm{I} 3 \mathrm{~A}-224 \mathrm{C}-3 \mathrm{IIC}$ & ChII \\
\hline 37 & $\mathrm{~T}$ & $\mathrm{I} 26 \mathrm{C}-294 \mathrm{~T}$ & Pkri, Pkr2, TA4, TA5 \\
\hline 38 & $\mathrm{~T} 2 \mathrm{~b}$ & I26C-189T-292T-294T-296T & Pkr5 \\
\hline 39 & $\mathrm{~T}$ & 086C-126C-140C-294T-296T & TAI5 \\
\hline 40 & TI & I26C-I63G-I86T-I89C-294T & Stsio \\
\hline $4 \mathrm{I}$ & $\mathrm{J}$ & 069 T-126C & ChI \\
\hline 42 & $\mathrm{H}$ & $366 \mathrm{~T}$ & $\mathrm{Ch} 2$ \\
\hline 43 & $\mathrm{H}$ & IIIT-362C & ChI4 \\
\hline 44 & W & $223 \mathrm{~T}-292 \mathrm{~T}$ & Chio \\
\hline
\end{tabular}


